\title{
外来食肉类北美水貂在新疆阿勒泰地区的入侵及潜在 影响探讨
}

黄元骏 ${ }^{1,2}$, 崔绍朋 ${ }^{1,2}$, 李娜 ${ }^{1,2}$, 李春旺 ${ }^{1,2}$, 蒋志刚 ${ }^{1,2 *}$

1. 中国科学院动物研究所动物生态与保护生物学重点实验室, 北京 100101 ;

2. 中国科学院大学, 北京 100049

*联系人, E-mail: jiangzg@ioz.ac.cn

2016-07-19 收稿, 2016-09-21 修回, 2016-09-22 接受, 2016-12-07 网络版发表

国家科技基础性工作专项(2013FY110300)资助

摘要北美水貂(Neovison vison)引入至欧洲后，逃逸扩散至欧洲大部分地区. 北美水貂对当地中小型动物构成 危害, 并可能携带病原, 已被定性为入侵物种。近年新疆阿尔泰山南部的森林公园和自然保护区均有北美水貂记 录, 本课题组在阿勒泰野外考察中也发现了北美水貂. 北美水貂在中国境外的阿尔泰山北部已有入侵种群, 不排 除中国境内的北美水貂为境外入侵. 北美水貂为我国首种外来入侵的食肉类动物, 为机会主义捕食者, 受其影响 的物种多. 因而, 预测北美水貂的潜在分布区, 调查潜在受影响物种十分必要. 本文从野外调查、潜在适生区、受 影响物种及野生动物疫病等多个角度评估了北美水貂在我国的入侵风险. 全球范围的适生区模拟显示, 除原产地 外, 欧洲、中亚阿尔泰山地区及我国长江中下游流域亦为北美水貂的主要高适生区. 北美水貂对当地特有水禽和 鱼类的影响较大, 应重点关注新疆地区特有小型鱼类. 此外, 我国和水貂生态位相似的欧亚水獭(Lutra lutra)、亚洲 小爪水獭(Aonyx cinerea)、江獭(Lutrogale perspicillata)处境濒危, 增加了北美水貂入侵的成功率. 我国为水貂养殖大 国, 三大水貂疫病在我国均有暴发记录, 且被证明可传染至野生动物, 故应加强对国内毛皮兽养殖的生态安全评估.

关键词北美水貂, 外来物种, 阿尔泰山, 适生区模拟, 野生动物疫病

北美水貂(Neovison vison (Schreber, 1777)), 也称 美洲水貂. 外形似鼠(Mustela spp.), 体长约 $35 \mathrm{~cm}$, 尾长约 $17 \mathrm{~cm}$, 体重约 $1 \mathrm{~kg}^{[1,2]}$. 原产北美大陆 $30^{\circ} \mathrm{N}$ 以 北的区域, 有 14 个亚种 ${ }^{[1]}$. 北美水貂为重要的毛皮 兽, 野生型披棕黑或深棕色针毛, 养殖品种有带黑短 毛的美国短毛黑、白化种和油亮棕毛的马赫根尼 (Mahogany)等 ${ }^{[3]}$. 传统意义上的水貂(Minks)包括北 美水貂和欧洲水貂 (Mustela lutreola), 北美水貂原为 鼠属 (Mustela) 物种, 后因头骨和细胞生化证据而被 划归至美洲水鼠属(Neovison $)^{[4,5]}$. 两者识别特征为欧 洲水貂吻部上下唇均具白色斑, 北美水貂仅下唇具
白斑或上下唇均无白斑 ${ }^{[2,6]}$. 欧洲水貂属 “极 危”(critically endangered, CR)物种, 种群稀少, 现仅 在中东欧地区有零星分布, 同时受到人侵的北美水 貂威胁 ${ }^{[1]}$.

北美水貂栖息于温带森林河岸, 也会到远离水域 的灌丛受食. 北美水貂营穴于廄鼠(Ondatra zibethica) 废弃的泥窟或岸边岩缝、枯木中, 具独行性 ${ }^{[2]}$. 北美 水貂是机会主义捕食者, 食谱包括水生及陆生中小 型动物及其卵，且可以通过偷袭、溺毕来捕杀与自己 体型相仿的动物 ${ }^{[2]}$. 水貂存在“过度杀戮行为”(surplus killing)，单只水貂可杀死整群地面营巢鸟类 ${ }^{[7,8]}$. 在英 
国, 人侵的北美水貂几乎将当地水鼠(Arvicola amphibius) 捕食殆尽, 也使当地水禽大幅减少 ${ }^{[1,8]}$. 北美 水貂适应性强, 在欧洲多个国家迅速建立了种群, 甚 至在南美也有人侵记录 ${ }^{[7,9,10]}$. 北美水貂人侵对当地 野生动物及渔业、养禽业造成危害, 且可能携带病原, 已被定性为人侵物种 ${ }^{[8,11]}$.

北美水貂在 20 世纪初由北美引至欧洲, 又于 20 世纪中叶引入我国 ${ }^{[6,11,12]} .20$ 世纪末, Geptner等人 ${ }^{[6]}$ 记 载了俄罗斯境内阿尔泰山北部的北美水貂种群和生 物学研究, 并提及中国新疆的天山一带有引种. 2010 年前后, 中国境内阿尔泰山南部的阿勒泰地区陆续 有野外水貂的正式记录, 但多有不准确之处 ${ }^{[13,14]}$. 刘 晏良 ${ }^{[14]}$ 将水貂列入喀纳斯自然保护区的兽类名录中, 但将其误定为欧洲水貂. 袁国映 ${ }^{[13]}$ 误将北美水貂和 欧洲水貂皆列人新疆人侵物种名录中, 且多个报道 将中国的野外水貂介绍为“珍稀物种”(表 $\mathrm{S} 1$ ). 通过实 地调查和资料收集, 在阿勒泰的布尔津县喀纳斯自 然保护区、富蕴县大小东沟林区、阿勒泰市及哈巴河 周边地区, 确证了野外水貂的记录, 且均为北美水 貂. 中国其他地区, 包括养貂规模大的华东地区, 尚 未见野外水貂的报道 ${ }^{[15]}$. 一些欧洲貂场, 尤其是东 欧和俄罗斯貂场, 有通过野外放养水貂提高毛皮质 量的做法, 也有放生遗弃养殖水貂的现象 ${ }^{[6]}$. 由于北 美水貂已在阿尔泰山北部建立种群多年, 阿勒泰的 水貂可能是境外扩散至我国的种群 ${ }^{[6,8,16]}$. 此外, 水 貂人侵的额尔齐斯河在我国属于孤立的水系, 一定 程度上延缓了水貂向内地扩散.

研究显示, 北美水貂的人侵与当地水獭种群衰 退有关. 水獭会排斥领域中的水貂, 但同时也会感染 北美水貂携带的病原 ${ }^{[9,17]}$. 我国分布的欧亚水獭 (Lutra lutra)、亚洲小爪水獭(Aonyx cinerea)、江獭 (Lutrogale perspicillata) 3种水獭已日渐稀少, 且均被 评为 “濒危(endangered, EN)”, ${ }^{18,19]}$. 北美水貂在我国 的发现点处于欧亚水獭指名亚种(L. lutra lutra)的分 布范围, 后者仅分布于新疆北部及东北省区 ${ }^{[20,21]}$. 与 长白山种群相比, 阿尔泰山的水獭种群研究匮乏, 很 可能已经绝迹 ${ }^{[2,23]}$. 北美水貂在阿勒泰地区的人侵 对当地水獭保护带来了新的挑战.

北美水貂为我国野外发现的首种外来食肉目动 物, 在我国外来种中属于顶级捕食者(近年虽有“蓝 狐” 等北极狐(Alopex lagopus) 养殖品种放生的报道, 但 “蓝狐”在野外生存能力有限, 尚未被国际列为人
侵物种, 且野生动物管理部门有组织捕回, 其人侵能 力有待观察 ${ }^{[24]}$ ). 人侵的北美水貂具有监测捕捉难、潜 在影响大等特点, 应受到充分关注. 为向北美水貂的 人侵防控提供资料, 运用MaxEnt模型, 基于数据库和 实地调查获得的分布点, 经过人工校对后模拟北美水 貂在全球范围的气候潜在适生区, 进而分析中国境内 和周边的适生区域, 并评估可能受影响的物种, 对未 来人侵进行预警. 同时通过文献检索北美水貂所携带 的病原, 分析同生态位的水獭现状. 希望能向当地决 策部署提供参考资料, 加强对国内毛皮兽场的管理监 督, 并对国内食肉类人侵种的防治带来启示.

\section{1 方法}

\section{1 北美水榴适生区预测}

用MaxEnt v3.3.3e对北美水貂在全球适生区进行 了模拟, 然后在同一结果下, 选取中国地理范围进行 进一步探讨 ${ }^{[25]}$. MaxEnt模型基于“生态位保守性假 说”(niche conservatism hypothesis) 和 “最大熵原 则”(the maximum-entropy principle), 根据物种已知 分布点及环境因子投射到地理坐标, 以实现对该物 种适生区的模拟 ${ }^{[25,26]}$. MaxEnt模型可用于人侵物种 预测、濒危物种重引人以及生态位理论研究 ${ }^{[27]}$.

根据野外考察和文献获得北美水貂的国内分布 点, 又从全球生物多样性信息网络数据库 (global biodiversity information facility, GBIF)获取国外分布 点 ${ }^{[28]}$, 获得原产及人侵地分布点共 11650 个. 经人工 校对核实, 删除圈养、信息缺乏、偏离已知分布地的 点, 同时删除相距在 $10 \mathrm{~km}$ 以内的过近点. 最后共获 得3251个分布点(表S1).

采用WorldClim的全球尺度、30"精度的19种气候 因子, 即Bio1 Bio19 (表 $S 2)^{[29]}$. 尽管设立伪不存在 点(pseudo absent) 能有助于矫正分布点的采样偏差, 但由于北美水貂是在被长期监测的物种, 其分布点 相对充裕均衡, 分布点较能切实反映实际分布情况, 且初次模拟情况较好, 故暂未运用伪不存在点 ${ }^{[25]}$. 由于北美水貂是适应性强的机会主义掠食者, 有报 道指出北美水貂在人侵地会根据当地生物和环境因 素而改变生境偏好. 在竞争压力大的地区，北美水貂 甚至扩散至较远离河流的环境 ${ }^{[9]}$. MaxEnt模型基于生 态位保守性假说, 而现实上的此类生态位漂移(niche shift)现象，会造成模拟适宜分布区的低估 ${ }^{[26]}$. 由于 
本研究旨在为生物人侵提供预警防范的资料, 故除 基本气候因子外, 未增加额外因子进行预测. 同时, 北美水貂来源复杂, 在高度集约化养殖地区, 貂场位 于人类活动较高的场所, 人侵种群出现在城市或市 郊; 而作坊式生产地区, 貂场位于人类活动较低的乡 村, 甚至直接引种到野外放养, 此时人侵种群出现在 郊野 ${ }^{[6,8,11]}$. 北美水貂的人侵点涵盖市区公园至自然保 护区, 所以并没有加人人类活动因子进行运算, 而是 分析时通过结合当地人类活动情况进行讨论.

采用 $25 \%$ 的分布点作检验, 模型运用Bootstrap法 重复运算 15 次, 最大迭代次数 5000 次进行运算. 采用 曲线下面积法 (area under the curve, AUC)评价结果的 准确性, 使用Jackknife评价各环境因子对北美水貂 分布的贡献. 讨论中以模拟得分达 0.8 以上为高适生 区(图1为鲜红色, 图 2 为橘红色), 0.2 以下为低适生区 (图1为深蓝色, 图2为苍蓝色) $)^{[25]}$.

\section{2 现受北美水貂潜在影响的脊椎动物评估}

根据国家科技基础性专项“中俄哈蒙边境地区特 有动物与动物地理研究” 调查的结果, 对当前北美水 貂在阿勒泰地区布尔津县、哈巴河县以及富蕴县中可 能受影响的脊椎动物列举评估, 涵盖潜在被捕食物 种及潜在竞争物种. 收集当地与水貂同生境的物种, 被捕食物种中选取体型与水貂相近或较小(不小于
$10 \mathrm{~cm})$ 的物种; 竞争物种中选取食性与水貂相仿, 体 型和水貂相当的物种. 不考虑外来物种、来源不明种 和已灭绝种, 重点列出濒危物种、特有物种、水边或 地面营巢物种及已有受影响记录的物种.

采用野外调查的物种记录，同时进行文献调研. 除采集物种名录外，也收集体型、生境、濒危等级、 特有性等信息, 查阅了《中国内陆鱼类物种与分

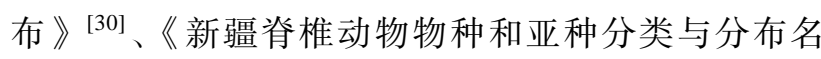
录》 ${ }^{[31]}$ 、 《阿勒泰生态环境》 ${ }^{[10]}$ 、《中国哺乳动物多 样性及地理分布》 ${ }^{[19]}$ 《 《中国兽类野外手册》 ${ }^{[21] 、 《 中 ~}$ 国鸟类野外手册》 ${ }^{[32]}$ 《《新疆生物多样性分布与评 价》 [13]、“中国脊椎动物红色名录” ${ }^{[18]}$ 和 IUCN Redlists ${ }^{[1]}$ 和Fishbase.org ${ }^{[33]}$ 等文献与数据库.

根据不同物种特性, 对当前潜在受影响的物种 分 $1,2,3$ 级进行受影响评估: 1 级为潜在影响最大的物 种, 即栖息或繁育环境与水貂生境相同的受威胁物 种或中国特有种、新疆特有种; 2 级为中度受影响的物 种, 包含繁育环境和水貂活动生境相同的非特有、非 濒危种或是在国外严重受水貂影响的物种; 3级为其 他与水貂生境相似的物种(表S3).

\section{3 北美水貂对我国欧亚水獭的潜在影响和所携 带的野生动物疫病}

根据《中国哺乳动物多样性及地理分布》确定中

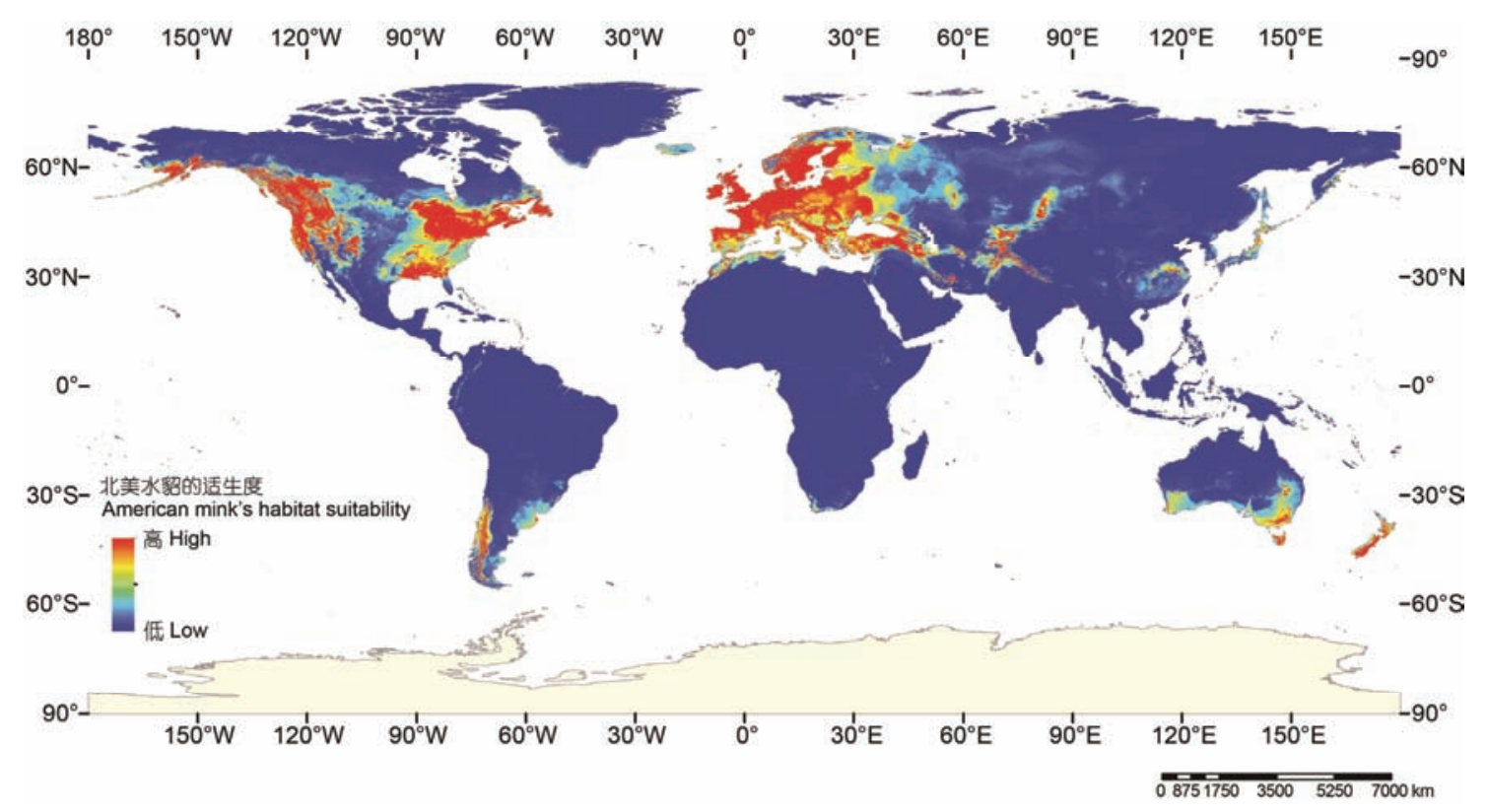

图 1 全球北美水貂的分布区模拟

Figure 1 Habitat simulation of American minks at global scale 


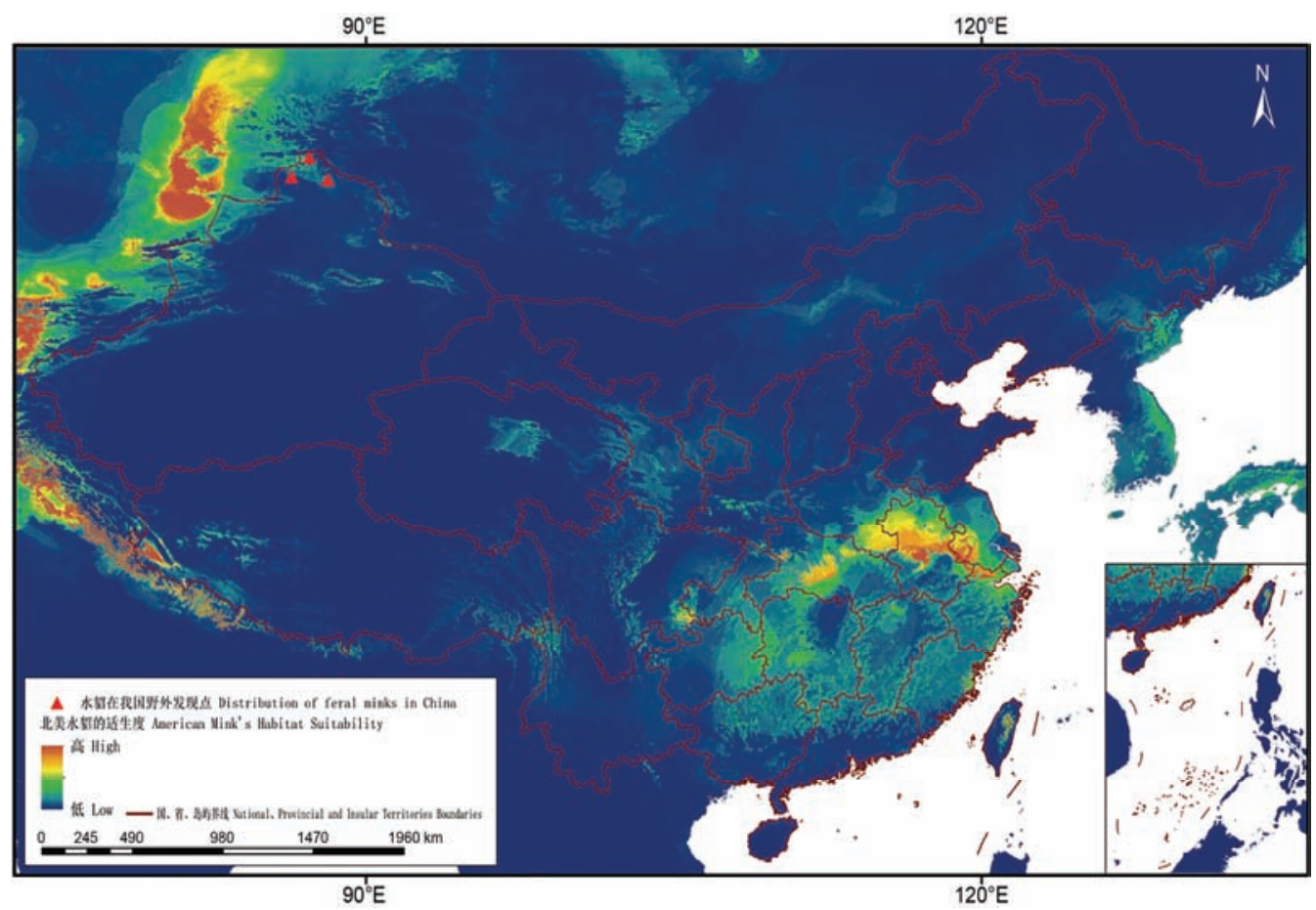

图 2 北美水貂在国内的适生区与发现点

Figure 2 Suitable habitat and records of American minks in China

国欧亚水獭的分布 ${ }^{[19]}$, 并同时检索我国 21世纪欧亚 水獭的发现点. 获得我国欧亚水獭的分布范围和最 近记录后, 与北美水貂的当前分布及适生区进行叠 加分析, 讨论北美水貂和本地水獭的关系, 并通过文 献调研北美水貂携带的传染病.

\section{2 结果与讨论}

\section{1 北美水貂的适生区模拟}

模拟结果显示(图1), 北美洲西部沿岸的科迪勒 拉山系(Cordillera Mountains)及东部的密西西比平原 (Mississippi Alluvial Plain)和五大湖地区(Great Lakes Region)均存在大片高适生区. 南美洲南端的巴塔哥 尼亚高原(Patagonia Plateau)也有适生区, 印证了当 地合恩角生物圈保护区(The Cape Horn Biosphere Reserve)的人侵事件 ${ }^{[10]}$. 东南端的拉普拉塔平原(Río de la Plata Basin)也有中等适生区, 符合当地北部的 人侵记录 ${ }^{[28]}$. 大洋洲尚未有记录, 但新西兰存在大 片适生区. 澳大利亚的东南与西南部, 以及塔斯马尼 亚岛(Tasmania)也存在一定适生区.

在旧大陆中, 几乎整个欧洲大陆及大不列颠岛
(Great Britain)均为高适生区，与人侵高发地相符 ${ }^{[13]}$. 非洲邻近欧洲的阿特拉斯山脉(Atlas Mountains)和南 端的好望角(Cape of Good Hope)存在适生区. 在西 亚, 毗邻欧洲的小亚细亚半岛(Asia Minor Peninsula), 亚美尼亚高原(Armenian Highland)及其两侧的扎格 罗斯山脉 (Zagros Mountains) 与厄尔布尔士山脉 (Elburz Mountains)也存在高适生区. 在北亚, 乌拉尔 山脉(Ural Mountains)南端的乌拉尔河(Ural River)上 游流域有较适宜生境. 西伯利亚南部阿尔泰-萨彦岭 地区 (Altai-Sayan Region), 连带中亚的天山山脉 (Tianshan Mountains)、帕米尔高原(Pamir Mountains) 的兴都库什山脉(Hindu Kush Mountains), 直到南亚 的苏莱曼山脉(Sulaiman Mountains)与喜马拉雅山脉 (Himalaya Mountains)西段, 均是北美水貂的适生区. 东亚方面, 中国东部地区、日本、朝鲜半岛及俄罗斯 远东地区的锡霍特山脉(Sikhote-Alin Mountains)、库 页岛(Sakhalin Island)、勘察加半岛 (Kamchatka Peninsula)均有中高适宜度的生境.

在中国, 北美水貂适生区位于长江中下游流域 与台湾中部山脉(图2). 其中四川省东南部、湖北省中 西部、河南省东南部、安徽省北部、江苏省西南部、 
浙江省西北部人侵风险较大, 而整个华南地区也有 中等适生区. 长白山脉一带, 秦岭山脉, 陇中高原, 四川中部的岷山、邛崃山, 青海湖周边地区, 云南的 怒山, 西藏朗钦藏布与昂拉仁错周边湖泊, 新疆中部 博格达山、博罗科努山, 新疆北部的塔尔巴哈台山、 阿尔泰山均散布着一定的适生区.

在北美水貂的原产地北美大陆, 其东西两岸为 其高适生区. 其中东部地区湖泊众多, 河网密集, 而 西部山地则有多处泰加林和雪山融水, 两地气候适 宜水貂分布. 欧洲大部为山地, 且气候温和湿润与原 产地相似, 因而亦为高适生区. 同样, 我国东部地区 水系密布, 气候也适宜北美水貂生存, 但高强度人类 活动带来的污染等因素可能会降低水貂的人侵成功 率. 值得注意的是, 大部分高适生区多处于沿海地 区, 应当加强港口检查. 同时, 中亚山脉则是独特的 内陆高适生区. 中亚山脉的南部紧邻我国西藏, 但高 海拔和陡峭地形也可能会降低水貂的人侵成功率. 而中亚山脉北部, 紧邻我国新疆的阿尔泰山地区, 已 经有北美水貂报道. 水貂可沿水系扩散, 虽中亚地区 的多条内流河可一定程度上延缓北美水貂的扩散, 但其中有多种特有鱼类. 因而应重点关注我国西北 地区的水貂防控, 加强当地特有水生生物的保育 监测 ${ }^{[6,14]}$.

模型检验显示, AUC值为 0.924 (图S1), 模型预 测精度较好 ${ }^{[25]}$. Jackknife评价结果显示(图S2), bio1 (年均温度)对北美水貂分布起最重要的作用. 其余依 次为bio11 (最冷月均温)、bio6 (最冷月最低温)、bio9 (最旱季均温)、bio14 (最旱月降水量)、bio19 (最冷季 均温)、bio17 (最旱季降水量)、bio10 (最暖月均温). 而 bio13 (最湿月降水量)和bio18 (最暖季均温)起到的作 用最小.

\section{2 现受北美水貂潜在影响的本上脊椎动物}

阿勒泰地区的布尔津县、哈巴河县以及富蕴县有 149种脊椎动物可能受北美水貂影响 (表S3), 包括鱼 类 15 种、两栖类 1 种、爬行类 2 种、兽类 36 种、鸟类 95 种, 其中 8 种为北美水貂的潜在竞争者, 其余 141 种为 潜在猎物.

北美水貂出现的额尔齐斯河水系, 是多种新疆 特有鱼类的分布地 ${ }^{[30]}$. 15 种北美水貂的潜在鱼类猎 物中, 有 11 种是新疆特有种, 包含当地唯一的中国特 有种(阿尔泰杜父鱼 (Cottus altaicos)) 和濒危种(细鳞
鲑 (Brachymystax lenok)), 11 种鱼类评为 1 级受影响. 人侵阿尔泰山的北美水貂主要捕食鱥(Phoxinus spp.)、杜父鱼类(Cottoidea)和鰕虎鱼类 ${ }^{[6]}$. 人侵的北 美水貂亦会使当地河流的鲑鳟鱼类(Salmonid)数量减 少 $^{[8]}$, 因而应加强阿尔泰杜父鱼监测, 并关注阿勒泰 鱥(P. ujmonensis)、细鳞鲭等特有鱼类.

当地与水貂同生境的两栖爬行类较少, 是水貂 的兼捕猎物 ${ }^{[6]}$, 但由于存在特有两栖爬行类, 给予其 一定受影响度. 重点受水貂影响的为小型鸟兽, 在 28 种潜在兽类猎物中, 1 种属于易危(vulnerable, VU), 即小飞鼠(Pteromys volans), 11种为新疆特有种. 田 鼠(Microtus spp.) 为北美水貂原产地的常见猎物 ${ }^{[1]}$, 但由于数量较多, 仅对新疆特有种黑田鼠(M. agrestis)与根田鼠(M. arvalis) 被评以高受影响. 与此相近 的各种鼠类 (Myodes spp., Alticola spp., Arvicola spp.) 是北美水貂的习见猎物. 其中应重点关注水滔 ( $A$. amphibius), 此种在英国由于北美水貂的捕食而濒 危 ${ }^{[1,8]}$. 兔类和鼠兔 (Ochotonidae) 也是北美水貂在开 阔生境的主要猎物 ${ }^{[34]}$.

北美水貂喜食地面及低矮灌丛鸟巢中的雉鸟和 卵 $^{[8]}$. 因而中小型鸟类中, 首先是水禽、涉禽受北美 水貂的影响最大. 95 种潜在鸟类猎物中, 约 $2 / 3$ (61种) 为水边栖息种类, 其中有 1 种 $\mathrm{CR}$ 一白头硬尾鸭 (Oxyura leucocephala), 1种 EN- - 遗鸥 (Larus relictus), 1 种 VU一一长脚秧鸡 (Crex crex). 除水鸟外, 开 阔生境中值得注意的物种有濒危种黄胸坐(Emberiza aureola), 泰加林和山地灌丛有松鸡 (Tetrao urogallus)、雪鸡(Tetraogallus spp.)、雷鸟(Lagopus spp.)等, 上述物种虽受影响度不如水鸟, 但不少为新疆特色 种, 故给予一定影响度. 国外已受水貂人侵影响的有 水鸡、鸥、鸭以及河乌(Cinclus spp.)等水鸟与泰加林 的松雀 (Pinicola enucleator) 等小型鸟类 ${ }^{[6,34]}$. 北美水 貂出现的阿尔泰山一带是诸多鸟类的繁殖地: 包括 大小东沟林区、哈巴河湿地、科克苏湿地等, 这些地 区大多是北美水貂的潜在适生点 ${ }^{[32]}$.

8 种北美水貂潜在竞争者均为鼠科动物. 除了黄 鼠 (M. sibirica) 和香鼠 (M. altaica) 外, 其他均处于易 危 $(\mathrm{VU})$ 或濒危 $(\mathrm{EN})^{[18]}$. 欧亚水獭和水貂的习性类似, 应受到最大关注. 此外, 北美水貂携带的犬瘟热等传 染病已对国外的水獭和艾鼠(M. eversmanii) 构成影 响 ${ }^{[8]}$. 因而, 列举北美水貂的常见病原, 对保护当地 受威胁的临科动物十分必要. 
当地有 51 种脊椎动物被评为 1 级潜在影响对象: 其中鱼类 11 种, 两栖类 1 种, 爬行类 1 种, 兽类 16 种, 鸟类 21 种. 62 种脊椎动物被评为 2 级潜在影响对象, 其中鸟类占绝大多数 (51种), 兽类 8 种, 鱼类 3 种. 另 有 35 种脊椎动物为 3 级潜在影响对象. 多数为鸟类, 而当地 $80 \%$ 的鱼类被评为 1 级潜在影响对象 (表 S3), 应加强对该两类群的监测.

\section{3 北美水貂与我国水獭的关系简析}

通过文献调研和数据检索, 共获得 43 个 21 世纪 水獭在中国分布点 (表S1). 分属13省 (区), 多是欧亚 水獭(图3). 目前仅东北、香港、三江源、唐家河、金 门及墨脱有较稳定种群, 其他均为偶见. 与理论分布 比, 目前我国水獭记录局限于中东部地区, 西北地区 或已绝迹. 国内3种水獭的处境均不乐观. 亚洲小爪 水獭与江獭在 1998年国内首次评估时即处于濒危状 态. 欧亚水獭的濒危等级自 2004年从易危“VU”上调 水獭不仅是对我国生物多样性的保护, 也对北美水 至濒危“EN”[18]. 我国水獭保育工作刻不容缓. 保育 貂的扩散起到一定遏制作用.

中国北美水貂的发现地是近年欧亚水獭绝迹的
新疆地区(图3). 欧亚水獭指名亚种原在阿尔泰山、伊 犁河谷和喀什周边有分布，在阿尔泰山的最后记录大 致在 20 世纪 80 年代 ${ }^{[35]}$, 不排除当地种群已灭绝. 长江 中下游流域的水獭已很罕见, 此地为水貂高适生区, 也有一定水貂存栏量, 但野外却未见水貂报道 ${ }^{[15,36]}$.

\section{4 北美水貂携带的常见传染病}

犬瘟热(canine distemper)是恶性传染病, 在我国 貂场已有多起报道 ${ }^{[37]}$. 犬瘟热可藉由流浪狗感染野 生动物. 该病是黑足鼠(M. nigripes)野外灭绝的主要 因素之一 ${ }^{[38]}$, 也造成非洲野犬(Lycaon pictus)、非洲 狮 (Panthera leo) 的数量下降 ${ }^{[38]}$, 甚至引发大熊猫 (Ailuropoda melanoleuca) 的死亡 ${ }^{[39]}$.

水貂可携带由病毒引发的水貂阿留申病(aleutian disease), 为进行性衰弱疾病, 主要感染鼠科动物 ${ }^{[40]}$. 在北美水貂人侵地，欧洲水貂和欧亚水獭均有检出 阿留申水貂病毒 ${ }^{[8]}$. 我国东北、山东及新疆均有病 例 ${ }^{[40]}$. 此病可严重影响繁殖力, 对野生动物危害大.

水貂病毒性肠炎(mink viral enteritis)也是北美水 貂的主要传染病 ${ }^{[41]}$. 野生动物中该病的研究较少, 已知可感染北美浣熊(Procyon lotor)等犬形亚目动

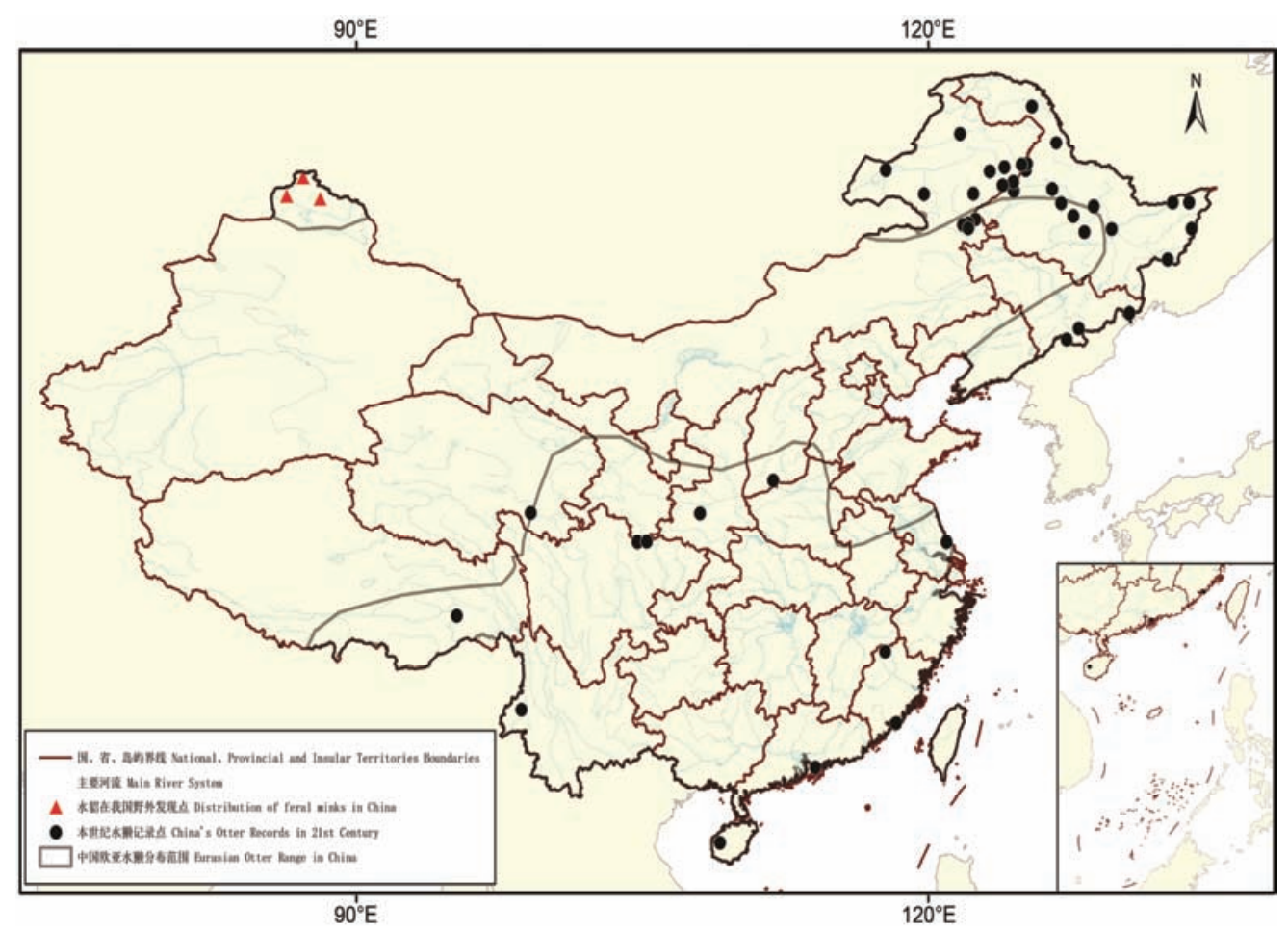

图 3 (网络版彩色)中国欧亚水獭的分布区与 21 世纪我国水獭和北美水貂的分布点

Figure 3 (Color online) Distribution range and 21st century's records of Eurasian otters and American minks in China 
物 ${ }^{[42]}$. 此病可由水或食物传播, 病媒多, 是水獭种群 的潜在威胁 ${ }^{[41]}$.

\section{3 结论}

北美水貂于 1920 年左右引人欧洲, 1930年起便发 现野外归化种群 ${ }^{[11]}$. 80多年后, 北美水貂在欧洲已十 分常见 ${ }^{[8,16]}$. 英国境内的野化水貂已经突破十万只, 对当地动物带来严重影响 ${ }^{[8,43]}$. 除了弃养外, 俄罗斯 乡村有野外散养水貂的做法, 导致北美水貂已在阿 尔泰山北部建立种群 ${ }^{[6]}$.

我国东部有多个养貂大省, 其中山东水貂存栏 量为 4627 万只, 占全国的 $80.5 \%$, 其次是辽宁 $(13.8 \%)$ 及黑龙江 $(3.5 \%)^{[36]}$. 20世纪50 60年代, 黑龙江和吉 林曾有逃貂事件，但有关部门已及时捕回 ${ }^{[12]}$. 现在, 我国出现水貂的地点却多是新疆北部阿勒泰的郊野. 新疆地区于 20 世纪 70 年代引人水貂养殖, 早年引人 的水貂多为近野生型的标准色水貂, 而近年多引人 美国短毛黑、丹麦红眼白水貂等黑化、白化品种 ${ }^{[3,44]}$. 然而近年我国水貂的报道除阿勒泰市区的为美国短毛 黑外, 其余个体毛色多似野生型, 类似马赫根尼品种. 故而从地点和毛色上看这些水貂是国外扩散而来.

另一方面, 国内养貂场也存在逃逸风险. 我国近 年水貂存栏量急增, 2013年曾突破8000万只, 我国一 跃成为世界水貂养殖第一大国 ${ }^{[15]}$. 然而, 随着 2014 年国际貂皮市场崩溃, 我国2015年的水貂存栏量下 降到 5700 万余只 ${ }^{[36]}$. 养殖户除了杀貂取皮降低存栏 量外, 遗弃放生也是降低损失的手段, 后者会对生态 造成严重损害, 诸多外来物种便是被养殖户遗弃而 成为人侵物种 ${ }^{[45]}$.
北美水貂生境隐蔽、单独生活、密度较小, 较难 监测统计种群情况. 20世纪末, 俄罗斯推算约有 3 4 万只野化北美水貂，其中 $80 \%$ 产于阿尔泰地区、克拉 斯诺亚尔斯克边疆区和伯力地区 ${ }^{[6]}$. 目前国内水貂多 发现于人迹罕至的自然保护区和林区. 实地调查与 访问得知, 水貂在喀纳斯自然保护区和大小东沟林 区并不罕见，通过痕迹和资料推算，在适宜生境每 10 $\mathrm{km}^{2}$ 至少存在1 2只.

北美水貂的生境特征为湿润凉爽的山地或丘陵 地区, 低温和旱期降水量对水貂分布影响较大. 但水 貂的生态位漂移会使生境更难预测, 且对更多物种 造成影响 ${ }^{[9]}$. 故而评估可能受水貂影响的物种, 可进 行前瞻性管理. 在竞争物种中, 水獭的水下受食能力 和体型均强于水貂, 且具有较强的领域性, 可通过竞 争排斥水貂 ${ }^{[17]}$. 通过水獭复育来遏制水貂扩散是一 个潜在思路.

新疆地处欧亚大陆地理中心, 是地球上离海洋 最远的封闭地区. 然而, 新疆面临着严重的外来物种 人侵风险。Zhang 和Jiang ${ }^{[45]}$ 发现，在过去的 64 年中， 新疆已经记录了 128 种外来种, 其中 $38 \%$ 已经成为人 侵种, 危及了当地的生物多样性, 造成了经济损失.

北美水貂是我国野外发现的首个外来食肉类物 种, 其习性和影响力均有别于以往国内外来生物. 此 外, 国内水貂存栏量庞大, 且已有疫病的暴发记录. 因而除了控制境外向境内扩散外, 也应加强国内养 貂行业的监管, 对养殖户进行生态安全方面的教育, 禁止弃养. 同时，水獭的种群衰退也促使了北美水貂 的人侵成功. 故而, 除了制定针对食肉类外来种的应 对措施外, 也应反思国内中小型动物的保育工作.

\section{参考文献}

1 World Conservation Union (IUCN). IUCN Red List of Threatened Species [2016-6-19]. http://www.iucnredlist.org

2 Wilson D E, Mittermeier R A, Ruff S, et al. Handbook of the Mammals of the World: Carnivores. Barcelona: Lynx, 2009. 655

3 Hua S, Hua S F. Introduction and selection standard of minks breeds (in Chinese). Spec Econ Anim Plant, 2005, 4: 3-4 [华盛, 华树芳. 水貂品种简介及选种标准. 特种经济动植物, 2005, 4: 3-4]

4 Abramov A V. A taxonomic review of the genus Mustela (Mammalia, Carnivora). Zoosyst Ross, 2000, 8: 357

5 Wozencraft W C. Order Carnivora. In: Mammal Species of the World: A Taxonomic and Geographic Reference. 3rd ed. Washington: Smithsonian Institution Press, 2005

6 Geptner V G, Nasimovich A A, Bannikov A G, et al. Mammals of the Soviet Union: Pt. 1. Carnivora (Weasels; Additional species). 
Washington: Smithsonian Institution Libraries and National Science Foundation, 1988. 1391-1415

7 Harrington M C, Lauren A. The American mink: The triumph and tragedy of adaptation out of context. New Zeal J Zool, 2003, 30: 421-441

8 Global Invasive Species Database (GISD). Species profile Neovison vison [2016-06-19]. http://www.iucngisd.org

9 Bonesi L, Chanin P, Macdonald D W. Competition between Eurasian otter Lutra lutra and American mink Mustela vison probed by niche shift. Oikos, 2004, 106: 19-26

10 Ibarra J T, Fasola L, Macdonald D W, et al. Invasive American mink Mustela vison in wetlands of the Cape Horn Biosphere Reserve, southern Chile: What are they eating? Oryx, 2009, 43: 87-90

11 Bonesi L, Palazon S. The American mink in Europe: Status, impacts, and control. Biol Conserv, 2007, 134: 470-483

12 Guo W C, Yang Z K. Mink farming (in Chinese). Xinjiang Agric Sci, 1963, 12: 480-485 [郭文场, 杨智奎. 水貂的养殖. 新疆农业科 学, 1963, 12: 480-485]

13 Yuan G Y. Biodiversity Distributions and Assessment in Xinjiang (in Chinese). Urumqi: Xinjiang Science and Technology Publishing House, 2012. 78, 126 [袁国映. 新疆生物多样性分布与评价. 乌鲁木齐：新疆科学技术出版社, 2012. 78, 126]

14 Liu Y L. Altai's Ecological Environment (in Chinese). Beijing: China Environmental Science Press, 2010. 296 [刘晏良. 阿勒泰生态环 境. 北京: 中国环境科学出版社, 2010. 296]

15 Ma Z F, Yang K H, Wang S A, et al. Current situation, problems and our mission in mink farming (in Chinese). In: Proceedings of National Academic Seminar on Fur Animals. Changchun: Jilin Science and Technology Press, 2014. 3-7 [马泽芳, 杨康华，王书安，等. 养貂业目前的形势、存在的问题和我们的任务. 见: 2014 年全国毛皮动物专业学术研讨会论文集. 长春: 吉林科学技术出版社, 2014. 3-7]

16 Reynolds J C, Short M J, Leigh R J. Development of population control strategies for mink Mustela vison, using floating rafts as monitors and trap sites. Biol Conserv, 2004, 120: 533-543

17 Harris S, Yalden D W. Mammals of the British Isles: Handbook. London: Mammal Society, 2008

18 Jiang Z G, Jiang J P, Wang Y Z, et al. Red list of China's vertebrates (in Chinese). Biodiv Sci, 2016, 24: 500-551 [蒋志刚, 江建平, 王 跃招, 等. 中国脊椎动物红色名录. 生物多样性, 2016, 24: 500-551]

19 Jiang Z G, Ma Y, Wu Y, et al. China’s Mammal Diversity and Geographic Distribution (in Chinese). Beijing: Science Press, 2015 [蒋志 刚, 马勇, 吴毅, 等. 中国哺乳动物多样性及地理分布. 北京: 科学出版社, 2015]

20 Wang Y X. A Complete Checklist of Mammal Species and Subspecies in China (in Chinese). Beijing: China Forestry Publishing House, 2003 [王应祥. 中国哺乳动物种和亚种分类名录与分布大全. 北京: 中国林业出版社, 2003]

21 Smith A T, Xie Y. A Guide to the Mammals of China (in Chinese). Changsha: Hunan Education Press, 2009 [Smith A T, 解炎. 中国兽 类野外手册. 长沙: 湖南教育出版社, 2009]

22 Piao Z J, Sui Y C, Wang Q, et al. Population fluctuation and resource protection of otter (Lutra lutra) in Changbai mountain nature reserve (in Chinese). J Hydroecol, 2011, 32: 115-120 [朴正吉, 睢亚橙, 王群, 等. 长白山自然保护区水獭种群数量变动与资源保护. 水生态学杂志, 2011, 32: 115-120]

23 Zhang R, Yang L, Laguardia A, et al. Historical distribution of the otter (Lutra lutra) in north-east China according to historical records (1950-2014). Aquat Conserv, 2016, 26: 602-606

24 Wang J C. More than 500 foxes are released in Sihanba forest national park (in Chinese). For China, 2010, 11: 44 [王金成. 500 余只狐狸 在塞罕坝国家森林公园放生. 中国林业, 2010, 11: 44]

25 Young N, Carter L, Evangelista P. A MaxEnt Model v3.3.3e Tutorial (ArcGIS v10), 2011

26 Phillips S J, Anderson R P, Schapire R E. Maximum entropy modeling of species geographic distributions. Ecol Model, 2006, 190: 231-259

27 Zhang X A, Sui X Y, Lü Z, et al. A prediction of the global habitat of two invasive fishes (Pseudorasbora parva and Carassius auratus) from East Asia using MaxEnt (in Chinese). Biodiv Sci, 2014, 22: 182-188 [张熙鳌，隋晓云，吕植，等. 基于 MaxEnt 的两种人侵性 鱼类(麦穗鱼和鲫)的全球适生区预测. 生物多样性, 2014, 22: 182-188]

Global Biodiversity Information Facility. Global Biodiversity Information Facility Database: Free and open access to biodiversity ta [2016-06-19]. 2016. http://www.gbif.org

29 Hijmans R J, Cameron S E, Parra J L, et al. Very high resolution interpolated climate surfaces for global land areas. Int J Climatol, 2005, 25: $1965-1978$

30 Zhang C G, Zhao Y H. Species Diversity and Distribution of Inland Fishes in China (in Chinese). Beijing: Science Press, 2016 [张春光, 赵亚辉. 中国内陆鱼类物种与分布. 北京: 科学出版社, 2016]

31 Gao X Y. A Checklist on the Classification and Distribution of Vertebrates Species and Subspecies in Xinjiang (in Chinese). Urumqi: Xinjiang Sciences and Technology Publishing House, 2005 [高行宜. 新疆脊椎动物种和亚种分类与分布名录. 乌鲁木齐: 新疆科学 技术出版社, 2005] John M, Karen P, He F Q. A Field Guide to the Birds of China (in Chinese). Changsha: Hunan Education Press, 2003 [John M, Karen P, 
何芬奇. 中国鸟类野外手册. 长沙：湖南教育出版社, 2003] reserve (in Chinese). Shaanxi For Sci Technol, 20
工作现状及对策. 陕西林业科技, 2015, 5: 68-70]

40 Xu F Y, Wang S Z. Overview of Aleutian disease of mink (in Chinese). J Econ Anim, 2006, 10: 106-111 [徐凤宇, 王树志. 水貂阿留申 病概述. 经济动物学报, 2006, 10: 106-111]

41 Liao G A. Mink viral enteritis (in Chinese). China Livest Poult Infect Dis, 1990, 2: 53-56 [廖国安. 水貂病毒性肠炎. 中国畜禽传染 病, 1990, 2: 53-56]

42 Barker I K, Povey R C, Voigt D R. Response of mink, skunk, red fox and raccoon to inoculation with mink virus enteritis, feline panleukopenia and canine parvovirus and prevalence of antibody to parvovirus in wild carnivores in Ontario. Can J Comp Med, 1983, 47: 188

43 Iordan F, Rushton S P, Macdonald D W, et al. Predicting the spread of feral populations of the American mink in Italy: Is it too late for eradication? Biol Invasions, 2012, 14: 1895-1908

44 Si Z, Kai W. Aksu region in Xinjiang carried out mink farming (in Chinese). Freshwater Fish, 1979: 17 [思珍, 开文. 新疆阿克苏地区 开展水貂养殖. 淡水渔业, 1979: 17]

45 Zhang L B, Jiang Z G. Unveiling the status of alien animals in the arid zone of Asia. Peer J, 2015 4: e1545

\section{补充材料}

表 S1 北美水貂和水獭分布记录

表 S2 MaxEnt 模拟中用到的 19 种 WorldClim 环境因子

表 S3 拟受北美水貂影响的我国本土脊椎动物名录

图 S1 北美水貂分布区模拟的 AUC 曲线检验

图 S2 环境因子对北美水貂分布作用的 Jacknife 刀切法评价

本文以上补充材料见网络版 csb.scichina.com. 补充材料为作者提供的原始数据，作者对其学术质量和内容负责. 


\title{
Invasion and potential impacts of the first alien carnivore in China: American minks (Neovison vison) in Altai region, Xinjiang
}

\author{
HUANG YuanJun ${ }^{1,2}$, CUI ShaoPeng ${ }^{1,2}$, LI Na $^{1,2}$, LI ChunWang ${ }^{1,2} \&$ JIANG ZhiGang ${ }^{1,2^{*}}$ \\ ${ }^{1}$ Key Laboratory of Animal Ecology and Conservation Biology, Institute of Zoology, Chinese Academy of Sciences, Beijing 100101, China; \\ ${ }^{2}$ University of Chinese Academy of Sciences, Beijing 100049, China \\ ${ }^{*}$ Corresponding author, E-mail: jiangzg@ioz.ac.cn
}

American minks (Neovison vison), which cause great impacts on local small and median sized animals through direct predation and diseases tramission, had been characterized as an invasive species worldwide. As well-known fur animals, American minks were introduced to Europe in early 20th century, and to China in mid-20th century. American minks spread nearly entire Europe soon after escaping from fur farms in European countries, and they had already established naturalized population in northern Altai Mountain in Russia for years. Northern Altai Mountain is one of the main distribution areas of American minks in Russia. In recent years, American minks were reported in southern Altai mountains (Altai region, or Chinese Altai) in Xinjiang, China. American minks occurred in forest parks and national nature reserves in Altai region. Earlier records in China were misidentified as European minks or both of them. Based on field survey and photo identification, we confirmed that all these records were belong to American minks.

Although American minks had been imported to China for over half a century, now they were found in wild in north-western China instead of eastern China, where had more mink farms. Thus American minks found in Chinese Altai may be border-crossing invaders. Through field survey and investigation, American minks were not rare in the forest parks and nature reserves of Chinese Altai region, thus we suggested that American mink had already established populations in China.

We discussed the potential impacts of American minks invasion in China through habitat simulation, potential prey and competing species, and wildlife diseases. We discussed the current status of otters in China, which had similar niches to minks. Using MaxEnt model for habitats simulation at global scales, we predicted climate-suitable areas for American minks. We find that coastal regions of North America, south tip of South America, Europe, Eastern Asia, North Africa, South Eastern Australia and New Zealand harbor highly suitable habitats of American minks. All these coastal areas should be exceptionally precautious for live minks transport.

In addition, mountains of Central Asia are the only inland highly suitable habitats of American minks. Central Asia harbors plentiful endemic fishes, and should be precautious for American minks invasion. In China, Chinese Altai and middle to lower reaches of Yangtze River are highly suitable habitats for American minks, where otters are almost disappeared. As China's first alien carnivore, American minks will impose great predation pressures on endemic waterfowls and fishes, and will have impact on China's endangered otters and other mustelids.

All three major minks epidemic diseases: canine distemper, Aleutian disease and mink viral enteritis had already have outbreak records in Chinese mink farms, and theses diseases had been proven to transmit to wildlife. In addition, China the has largest mink farming industry of the world. Therefore, besides controlling border-crossing invasion, eco-security assessments should be strengthened in domestic mink farms.

\section{American minks, invasive species, Altai Mountain, habitat simulation, wildlife diseases}

doi: 10.1360/N972016-00801 